\title{
RESPON PERTUMBUHAN DAN DAYA HASIL SORGUM (Sorghum bicolor [L] Moench) DENGAN PEMBERIAN PUPUK FOSFOR DI LAHAN MASAM KABUPATEN SIMALUNGUN
}

\section{The Response of Growth and Production of Sorghum (Sorghum bicolor [L] Moench) to Phosphorus Fertilizer in the Acid Soil of Simalungun District}

\author{
Arvita Netti Sihaloho* dan Ringkop Situmeang \\ Program Studi Agroteknologi, Fakultas Pertanian Universitas Simalungun, \\ Jl. Sisingamangaraja, Pematangsiantar 21139
}

Alamat Korespondensi: netti.haloho@gmail.com

\begin{abstract}
ABSTRAK
Penelitian ini bertujuan untuk memperoleh dosis pupuk TSP yang sesuai untuk beberapa varietas sorgum dan mendapatkan varietas yang dapat berproduksi tinggi di tanah masam dataran tinggi Kabupaten Simalungun. Penelitian ini dilaksanakan pada bulan September 2019 sampai Desember 2019 di Kebun Percobaan Fakultas Pertanian Universitas Simalungun. Penelitian menggunakan Rancangan Acak Kelompok Faktorial (RAKF) dengan dua faktor dan tiga ulangan. Faktor pertama Varietas yaitu Numbu, Kawali, UPCA. Faktor kedua adalah Dosis pupuk TSP (P) yaitu 80,90 dan $100 \mathrm{~kg} / \mathrm{ha}$. Variabel yang diamati antara lain tinggi tanaman (cm), jumlah daun (helai), diameter batang $(\mathrm{cm})$, panjang malai $(\mathrm{cm})$, berat kering malai per plot $(\mathrm{g})$ dan berat 1000 butir $(\mathrm{g})$. Hasil penelitian menunjukkan bahwa penambahan pupuk fosfor sampai $100 \mathrm{~kg} / \mathrm{ha}$ dapat meningkatkan tinggi tanaman, jumlah daun, diameter batang, panjang malai, bobot malai dan bobot 1000 butir untuk semua varietas yang digunakan. Aplikasi dosis pupuk fosfor $100 \mathrm{~kg} / \mathrm{ha}$ pada varietas Numbu mampu menghasilkan bobot malai 88,38 g per tanaman dan setara dengan 6 t/ha..
\end{abstract}

Kata Kunci: hasil, pupuk fosfor, tanah masam, varietas sorgum

\begin{abstract}
The research aimed to obtain the dosage of TSP fertilizer was compatible with a few varieties of sorghum and obtain the varieties of sorghum can product high yield in the acid soil of highland in Simalungun District. The research was carried out in the field of the Faculty of Agricultural Simalungun University from September to December 2019. The experiment design was Factorial Randomized Block design (FRB) with two factors and three replications. The first factor was varieties consist of 3 varieties are Numbu (G1), Kawali (G2), UPCA (G3). The second factor was phosphorus fertilizer dose is 80.90 and $100 \mathrm{~kg} / \mathrm{ha}$. Observed parameters were plant height (cm), the number of leaves (strands), the diameter of the stem (cm), long panicles (cm), dry weight panicles/plot $(\mathrm{g})$, and weight of 1000 grains $(\mathrm{g})$. The result showed that the addition of fertilizer phosphorus to $100 \mathrm{~kg} / \mathrm{ha}$ can increase plant height, the number of leaves, the diameter of the stem, long panicles, dry weight panicles/plot, and weight of 1000 grains for all varieties are used. The fertilizer application dose of $100 \mathrm{~kg} / \mathrm{ha}$ on varieties Numbu variety produced $88.38 \mathrm{~g}$ panicles weight per plant and equal to $6 \mathrm{t} / \mathrm{ha}$.
\end{abstract}

Keywords: acid soil, phosphorus fertilizer, sorgum variety, yield

\section{PENDAHULUAN}

Laju pertumbuhan penduduk

Indonesia terus bertambah sehingga

kebutuhan jumlah pangan semakin

meningkat setiap tahun. Hal ini

menunjukkan bahwa ketahanan pangan

nasional sangat riskan bila hanya mengandalkan komoditas beras dan terigu.

Oleh sebab itu, salah satu upaya pengembangan pangan alternatif dan sangat potensial dari tanaman biji-bijian adalah sorgum. Sorgum merupakan alternatif untuk diversifikasi pangan yang bisa dikembangkan sebagai sumber pangan 
mengingat potensi dan kandungan nutrisinya (Suhardedi, 2015)

Tanaman sorgum memiliki kemampuan tumbuh hampir di setiap jenis tanah. Tanaman sorgum memiliki kelebihan dibandingkan dengan tanaman pangan lain yaitu tidak memerlukan masukan nutrisi yang tinggi, toleran terhadap kekurangan dan kelebihan air, lebih tahan terhadap serangan organisme pengganggu tanaman serta dapat tumbuh baik pada tanah marginal (Talanca et al., 2014)

Potensi yang dimiliki tanaman sorgum dapat digunakan sebagai suatu upaya pengembangan pada lahan kering dan lahan kritis. Seluruh bagian tanaman sorgum dapat dimanfaatkan seperti batang, biji, daun dan hasil limbah organiknya (Rahayu, 2012). Prayudi et al. (2019) menyatakan bahwa sorgum (Sorghum bicolor [L] Moench) adalah tanaman serealia yang memiliki potensi untuk dikembangkan sebagai sumber bahan pangan untuk mendukung program diversifikasi pangan. Sorgum memiliki kandungan nutrisi yang tinggi, bahkan kadar proteinnya lebih tinggi daripada beras. Sorgum memiliki kadar protein $11 \%$, sedangkan beras hanya $6,8 \%$. Kandungan nutrisi mikro lain yang dimiliki oleh sorgum adalah kalium, besi, fosfor, serta vitamin B (Subagio et al., 2013)

Salah satu permasalahan untuk pengembangan tanaman sorgum adalah pemupukan, sebab berhubungan erat dengan media tanam (Selvia et al., 2014). Puspitasari et al. (2018) yang menyatakan bahwa efisiensi pemupukan $\mathrm{P}$ pada umumnya sangat rendah yang disebabkan oleh fiksasi $\mathrm{P}$ dalam tanah sehingga unsur $\mathrm{P}$ yang diberikan tidak seluruhnya tersedia bagi tanaman. Tingginya fiksasi $\mathrm{P}$ dalam tanah menyebabkan penimbunan $\mathrm{P}$ dalam tanah dari waktu ke waktu selama pemberian pupuk $\mathrm{P}$ dilakukan. Sebagian besar pupuk $\mathrm{P}$ yang tidak terserap oleh tanaman tidak hilang tercuci, tetapi menjadi non labil $\mathrm{P}$ yang tidak tersedia bagi tanaman. Pemupukan adalah satu upaya untuk mengatasi kekurangan hara seperti hara $\mathrm{P}$ (fosfor). Fosfor adalah unsur hara makro yang memiliki peran penting dalam pertumbuhan. Salah satu faktor yang membatasi dalam budidaya tanaman untuk mendapatkan hasil yang optimum adalah ketersedian P dalam tanah (Winata et al., 2014).

Salah satu fungsi unsur $\mathrm{P}$ adalah membantu pertumbuhan akar tanaman, apabila pembentukan akar terhambat maka penyerapan unsur hara akan mengalami gangguan. Selain itu unsur $P$ juga berperan untuk mempercepat proses pembungaan, pembuahan dan pemasakan buah dan biji (Palmasari \& Riani, 2019). Saat proses pembungaan kebutuhan unsur $\mathrm{P}$ akan meningkat karena unsur $\mathrm{P}$ adalah komponen penyusun ATP yang berguna 
dalam proses transfer energi. Unsur $\mathrm{P}$ juga berperan dalam perangsangan tumbuhnya akar-akar baru dari tanaman muda dan benih (Suranto et al., 2015). Siregar et al. (2018) merekomendasikan pemupukan sorgum pada tanah latosol untuk hasil optimum adalah $44 \mathrm{~kg} \mathrm{P}_{2} \mathrm{O}_{5} / \mathrm{ha}$ atau 95,65 TSP/ha.

Penelitian mengenai dosis pupuk fosfor pada beberapa varietas telah dilakukan oleh (Sitepu et al., 2015) di lahan optimal, hasil yang diperoleh pada varietas Kawali mampu menghasilkan panjang malai $(26 \mathrm{~cm})$, bobot malai (105 g) dan bobot 1000 butir $(57,10 \mathrm{~g})$, sedangkan dalam penelitian ini akan dilakukan pemberian berbagai dosis pupuk $\mathrm{P}$ dan berbagai varietas di lahan marginal yang tersebar terutama di dataran tinggi sehingga berbeda dengan yang telah dilakukan oleh Sitepu et al. (2015). Penelitian sorgum di lahan marginal masih jarang dilakukan, sebagai tanaman pangan pengganti padi. Penelitian ini bertujuan untuk mendapatkan dosis pupuk fosfor yang tepat pada beberapa varietas sorgum untuk mendapatkan varietas yang dapat berproduksi tinggi di tanah masam dataran tinggi.

\section{METODE PENELITIAN}

Penelitian ini dilaksanakan pada bulan September 2019 sampai Desember 2019 di Lahan Kebun Percobaan Fakultas
Pertanian Universitas Simalungun dengan kondisi curah hujan 204-210 mm/bulan, suhu $24-28{ }^{0} \mathrm{C}$ dan kelembaban $75-80 \%$. Penelitian menggunakan Rancangan Acak Kelompok Faktorial (RAKF). Faktor pertama adalah Varietas dengan 3 taraf yaitu Numbu, Kawali, UPCA, sedangkan faktor kedua adalah Dosis pupuk fosfor dengan 3 taraf yaitu $80,90,100 \mathrm{~kg} / \mathrm{ha}$, sehingga diperoleh kombinasi perlakuan sebanyak 9 kombinasi dan diulang sebanyak 3 kali. Pupuk fosfor diberikan pada saat tanam dengan dosis sesuai dengan perlakuan, serta $180 \mathrm{~kg}$ N/ha dan $90 \mathrm{~kg}$ $\mathrm{K}_{2} \mathrm{O} /$ ha. Dosis pupuk yang diberikan berdasarkan kandungan unsur $\mathrm{N}$ dan $\mathrm{K}$ rendah dari hasil analisa tanah. Ukuran plot penelitian yang digunakan 3 x $4 \quad \mathrm{~m}$. Pengendalian hama dan penyakit dilakukan apabila terjadi indikasi serangan dengan penyemprotan insektisida Decis $25 \mathrm{EC}$ dan Dithane M-45.

Variabel yang diamati saat tanaman mulai berbunga antara lain tinggi tanaman (cm) diukur dari pangkal batang hingga ujung daun yang terpanjang, jumlah daun (helai) dengan cara menghitung jumlah helai daun pada tiap sampel tanaman, dan diameter batang $(\mathrm{cm})$. Pengukuran diameter batang menggunakan jangka sorong dengan terlebih dahulu membuat tanda di batang yang akan diukur yaitu $10 \mathrm{~cm}$ dari pangkal akar. Pengamatan menjelang panen antara lain panjang malai $(\mathrm{cm})$ diukur dari dasar 
malai sampai ujung malai, bobot kering malai (g) dikeringkan kemudian ditimbang dengan menggunakan timbangan digital, bobot 1000 butir (g) pada kadar air $16 \%$ dengan cara biji dirontokkan dari malai tanaman, dihitung sebanyak seribu biji (karena biji sorgum kecil sama seperti padi yg diukur 1.000 biji maka saya juga menimbang biji sorgum sebanyak 1.000 biji) lalu ditimbang dengan timbangan digital. Sampel diambil $10 \%$ (5 tanaman) dari seluruh tanaman tiap petakan Data hasil pengamatan dianalisis dengan analisis ragam dan bila berbeda nyata maka akan dilanjutkan dengan uji jarak berganda Duncan taraf kepercayaan $95 \%$ menggunakan SPSS 26.

\section{HASIL DAN PEMBAHASAN}

\section{Komponen Pertumbuhan Berbagai Varietas Sorgum dengan Pemberian Berbagai Dosis Pupuk Fosfor}

Hasil analisis sidik ragam pada Tabel 1 menunjukkan bahwa perlakuan pemberian dosis pupuk fosfor pada berbagai varietas sorgum untuk karakter tinggi tanaman, jumlah daun dan diameter batang berbeda nyata. Hal ini memperlihatkan bahwa semakin bertambah dosis pupuk fosfor yang diberikan maka akan terjadi peningkatan pertumbuhan vegetatif. Varietas yang memiliki respon pertumbuhan vegetatif terbaik adalah varietas UPCA yang berbeda nyata dengan dua varietas lainnya untuk diameter batang tetapi tidak berbeda nyata untuk tinggi tanaman dan jumlah daun.

Varietas UPCA dengan dosis pupuk $100 \mathrm{~kg} / \mathrm{ha}$ yang terbaik untuk tinggi tanaman $(182,66 \mathrm{~cm})$ dan diameter batang $(6,61 \mathrm{~cm})$, varietas Kawali terbaik untuk jumlah daun (11,21 helai) dan panjang malai $(20,15 \mathrm{~cm})$, tetapi secara analisa sidik ragam memperlihatkan perbedaan yang tidak nyata.

\section{Komponen Hasil Berbagai Varietas Sorgum dengan Pemberian Berbagai Dosis Pupuk Fosfor}

Berdasarkan hasil analisa sidik ragam pada Tabel 1 terlihat bahwa perlakuan pemberian dosis pupuk fosfor $(100 \mathrm{~kg} / \mathrm{ha})$ pada berbagai varietas untuk karakter panjang malai dan berat malai menunjukkan perbedaan yang nyata serta hasil uji lanjut menggunakan uji Duncan pada Tabel 2 menunjukkan bahwa panjang malai paling tinggi dihasilkan oleh varietas Kawali $(21,96 \mathrm{~cm})$ sedangkan berat malai paling berat $(88,38 \mathrm{~g})$ ditunjukan oleh varietas Numbu. Bobot seribu biji menunjukan tidak ada perbedaan yang nyata antar varietas dengan dosis aplikasi $\mathrm{P}$ yang berbeda (Tabel 2). Hasil penelitian ini menunjukkan bahwa secara umum semakin bertambah dosis pupuk fosfor yang diberikan maka produksi yang dihasilkan antara lain pada panjang malai dan bobot malai. 
Menurut deskripsi yang dikeluarkan oleh Balittan sereal (2014), varietas Kawali memiliki tinggi tanaman $135 \mathrm{~cm}$, panjang malai 28-29 $\mathrm{cm}$ dan potensi hasil 4-5 t/ha, varietas Numbu memiliki tinggi tanaman
$187 \mathrm{~cm}$, panjang malai $22-23 \mathrm{~cm}$ dan potensi hasil 4-5 ton/ha, sedangkan varietas UPCA memiliki tinggi tanaman $210 \mathrm{~cm}$, panjang malai $22-26 \mathrm{~cm}$ dan potensi hasil 4-4,9 t/ha..

Tabel 1. Hasil sidik ragam pengaruh pemberian pupuk fosfor terhadap karakter pertumbuhan dan hasil sorgum di tanah masam

\begin{tabular}{lclrlr}
\hline Variable pengamatan & Varietas $(\mathrm{V})$ & Pupuk P $(\mathrm{P})$ & Interaksi V x P \\
\hline Tinggi Tanaman & 8,78 n & 0,15 tn & $36,84 \mathrm{n}$ \\
Jumlah Daun & 0,03 tn & 0,67 tn & $3,43 \mathrm{n}$ \\
Diameter Batang & 0,73 tn & $8,53 \mathrm{n}$ & $47,45 \mathrm{n}$ \\
Panjang Malai & 0,56 tn & $5,34 \mathrm{n}$ & $4,73 \mathrm{n}$ \\
Berat Malai & 0,01 tn & $0,15 \mathrm{tn}$ & $3,13 \mathrm{n}$ \\
Bobot 1000 Biji & 0,24 tn & 0,23 tn & $4,93 \mathrm{n}$ \\
\hline
\end{tabular}

Keterangan: $\mathrm{n}=$ berbeda nyata pada $p=0,05$ dan $\mathrm{tn}=$ tidak berbeda nyata pada $p=0,05$.

Tabel 2. Karakter pertumbuhan dan hasil sorgum dengan pemberian pupuk fosfor dengan dosis berbeda pada tanah masam

\begin{tabular}{|c|c|c|c|c|c|c|c|}
\hline \multicolumn{2}{|c|}{ Perlakuan } & \multirow{2}{*}{$\begin{array}{c}\text { TT } \\
(\mathrm{cm})\end{array}$} & \multirow{2}{*}{$\begin{array}{c}\text { JD } \\
\text { (helai) }\end{array}$} & \multirow{2}{*}{$\begin{array}{l}\text { DB } \\
(\mathrm{cm})\end{array}$} & \multirow{2}{*}{$\begin{array}{l}\mathrm{PM} \\
(\mathrm{cm})\end{array}$} & \multirow{2}{*}{$\begin{array}{c}\mathrm{BM} \\
(\mathrm{g})\end{array}$} & \multirow{2}{*}{$\begin{array}{c}\text { BSB } \\
(\mathrm{g})\end{array}$} \\
\hline Varietas & Dosis $\mathrm{P}$ & & & & & & \\
\hline \multirow{3}{*}{ Numbu } & $80 \mathrm{~kg} / \mathrm{ha}$ & $141,78 \mathrm{~b}$ & $8,28 \mathrm{~b}$ & $2,45 \mathrm{f}$ & $18,60 \mathrm{~cd}$ & $59,80 \mathrm{~cd}$ & $21,31 \mathrm{a}$ \\
\hline & $90 \mathrm{~kg} / \mathrm{ha}$ & $153,68 \mathrm{~b}$ & $9,26 \mathrm{ab}$ & 2,69 ef & $18,29 \mathrm{~d}$ & $73,90 \mathrm{~b}$ & $21,63 \mathrm{a}$ \\
\hline & $100 \mathrm{~kg} / \mathrm{ha}$ & $174,72 \mathrm{ab}$ & $9,09 \mathrm{ab}$ & $4,07 \mathrm{~d}$ & $18,67 \mathrm{~cd}$ & 88,38 a & $22,40 \mathrm{a}$ \\
\hline \multirow{3}{*}{ Kawali } & $80 \mathrm{~kg} / \mathrm{ha}$ & $133,00 \mathrm{~b}$ & $7,04 \mathrm{~b}$ & 2,98 ef & $18,43 \mathrm{~cd}$ & $43,13 \mathrm{ef}$ & $20,14 \mathrm{ab}$ \\
\hline & $90 \mathrm{~kg} / \mathrm{ha}$ & $164,33 \mathrm{ab}$ & $10,91 \mathrm{a}$ & $3,19 \mathrm{e}$ & $20,06 \mathrm{~b}$ & $53,37 \mathrm{de}$ & $19,70 \mathrm{~b}$ \\
\hline & $100 \mathrm{~kg} / \mathrm{ha}$ & $174,72 \mathrm{ab}$ & $11,21 \mathrm{a}$ & $3,26 \mathrm{e}$ & $21,96 \mathrm{a}$ & $71,33 \mathrm{bc}$ & $21,86 \mathrm{a}$ \\
\hline \multirow{3}{*}{ UPCA } & $80 \mathrm{~kg} / \mathrm{ha}$ & $161,80 \mathrm{ab}$ & $7,26 \mathrm{~b}$ & $3,92 \mathrm{de}$ & $18,01 \mathrm{~d}$ & $27,39 \mathrm{f}$ & $21,90 \mathrm{a}$ \\
\hline & $90 \mathrm{~kg} / \mathrm{ha}$ & $173,83 \mathrm{ab}$ & $8,35 \mathrm{~b}$ & $5,64 \mathrm{~b}$ & $20,41 \mathrm{~b}$ & 42,43 ef & $21,17 \mathrm{a}$ \\
\hline & $100 \mathrm{~kg} / \mathrm{ha}$ & $182,66 \mathrm{a}$ & $9,89 a b$ & $6,61 \mathrm{a}$ & $20,46 \mathrm{~b}$ & 47,30 ef & $20,64 \mathrm{ab}$ \\
\hline
\end{tabular}

Keterangan : Angka yang diikuti dengan huruf yang sama pada kolom yang sama tidak berbeda nyata menurut Uji Jarak Berganda Duncan pada $p=0,05$. TT = tinggi tanaman; $\mathrm{JD}=$ jumlah daun; $\mathrm{DB}=$ diameter batang; $\mathrm{PM}=$ panjang malai; $\mathrm{BM}=$ berat malai; $\mathrm{BSB}=$ bobot 1000 biji.

Berdasarkan hasil penelitian yang diperoleh, pertumbuhan vegetatif dua varietas menunjukkan penurunan untuk karakter tinggi tanaman berdasarkan deskripsi tanamannya dan hanya varietas Kawali yang karakter tinggi tanamannya meningkat, dengan aplikasi pupuk fosfor $100 \mathrm{~kg} / \mathrm{ha}$. Karakter produksi pada varietas
Numbu dengan aplikasi pupuk fosfor 100 $\mathrm{kg} / \mathrm{ha}$ mampu menghasilkan 88,38 g bobot malai setiap tanaman sehingga diperkirakan setara dengan 6 t/ha. Begitu pula varietas Kawali apabila disetarakan mampu menghasilkan 4,8 t/ha sedangkan varietas UPCA hanya menghasilkan 3,2 t/ha. 
Hasil penelitian yang diperoleh menunjukkan bahwa semakin bertambah dosis pupuk fosfor yang diberikan pada ketiga varietas sorgum yang diteliti maka semakin baik pertumbuhan dan produksi sorgum. Pemberian pupuk fosfor yang meningkat menyebabkan pertumbuhan vegetatif ketiga varietas semakin baik, namun pertumbuhan vegetatif yang baik tidak menjamin pertumbuhan generatif yang baik juga. Hal ini terlihat pada Tabel 2 , pertumbuhan vegetatif yang baik terdapat pada varietas UPCA tetapi varietas Numbu yang mempunyai berat malai yang terberat dan panjang malai terpanjang adalah varietas Kawali.

Pemberian dosis pupuk fosfor 100 $\mathrm{kg} / \mathrm{h}$ a menyebabkan unsur P cukup tersedia bagi tanaman karena ketersediaan fosfor dipengaruhi kondisi tanah dan daya serap tanaman. Ketersediaan fosfor di dalam tanah dipengaruhi oleh $\mathrm{pH}$ tanah, tipe tanah, temperatur, bahan organik dan waktu aplikasi (Cinta et al., 2020.). Umumnya tanaman akan lebih peka pada kondisi defisiensi P, termasuk sorgum. Meskipun demikian, varietas sorgum memiliki tingkat toleransi yang berbeda terhadap defisiensi $\mathrm{P}$, terutama varietas Numbu sangat potensial untuk ditanam di berbagai kondisi lingkungan (Agustina et al., 2010) dan memiliki kebutuhan dosis fosfor yang berbeda pula (Marlina et al., 2015).
Bervariasinya hasil yang didapat menunjukkan adanya respon yang berbeda dari setiap varietas terhadap lingkungan. Perbedaan pertumbuhan tanaman dipengaruhi oleh faktor internal seperti gen dan hormon yang mempengaruhi pertumbuhan melalui sifat yang diwariskan. Faktor eksternal seperti unsur hara, air, suhu, kelembaban, dan cahaya juga memberi respon berbeda terhadap karakteristik suatu tanaman.

Sebagaimana diketahui bahwa tingginya produksi disebabkan oleh kemampuan adaptasi yang baik dari varietas tersebut dengan lingkungan tempat hidupnya. Hal ini juga kemungkinan disebabkan bahwa unsur fosfat merupakan bagian inti sel yang sangat penting dalam pembelahan sel dan untuk perkembangan jaringan meristem, dengan demikian fosfat dapat merangsang pertumbuhan akar dan tanaman muda, sehingga meningkatkan penyerapan unsur hara. Meningkatnya serapan hara maka proses metabolisme berjalan dengan optimal yang akan meningkatkan pembentukan protein, karbohidrat dan pati yang akan ditranslokasikan ke cadangan makanan yaitu malai, akibatnya malai yang terbentuk mempunyai berat lebih besar (Nuryani \& Haryono, 2019).

Hal ini sesuai dengan pernyataan Hutauruk et al. (2012) yang menyatakan fosfor merupakan bagian integral tanaman 
di bagian penyimpanan (storage) dan pemindahan (transfer) energi. Fosfor terlibat dalam penangkapan ADP (adenosine diphosphate) atau ATP (adenosin triphosphate), yang dipakai untuk menjalankan reaksi-reaksi yang memerlukan energi, seperti pembentukan sukrosa, tepung dan protein.

Tabel 3. Hasil Analisis Tanah Awal pada Lahan Percobaan

\begin{tabular}{lcc}
\hline \multicolumn{1}{c}{ Sifat tanah } & Nilai uji tanah & Status \\
\hline $\mathrm{pH}$ & 4,90 & Masam \\
$\mathrm{N}(\%)$ & 0,10 & Rendah \\
$\mathrm{P}_{2} \mathrm{O}_{5}(\mathrm{ppm})$ & 11,30 & Sedang \\
$\mathrm{K}(\mathrm{me} / 100 \mathrm{~g})$ & 0,20 & Rendah \\
$\mathrm{KTK}(\mathrm{me} / 100 \mathrm{~g})$ & 5,45 & Rendah \\
$\mathrm{C} / \mathrm{N}$ & 5,55 & Rendah \\
\hline
\end{tabular}

Tabel 3 menunjukkan kandungan fosfor tergolong sedang (11,3 ppm $\left.\mathrm{P}_{2} \mathrm{O}_{5}\right)$ sehingga penambahan dosis pupuk fosfor sampai dosis $100 \mathrm{~kg} / \mathrm{ha}$ masih meningkatkan pertumbuhan untuk semua varietas yang digunakan karena semakin bertambah dosis yang diberikan panjang malai dan berat malai semakin bertambah. Hal ini terjadi karena pupuk fosfor berperan saat masa generatif dan pembentukan biji tanaman terutama pada tanaman serelia dan umumnya fosfat diserap oleh tanaman kebanyakan pada fase generatif yaitu sekitar $90 \%$ dari yang diberikan ke tanah.

Wahyuningrum et al. (2015) menyatakan apabila tanaman sudah memasuki fase generatif (masak) sebagian besar P dimobilisasi ke biji dan buah atau bagian generatif yang lain. Serapan hara $\mathrm{P}$ saat vegetatif yaitu mulai perkecambahan hingga berbunga, total serapan tidak lebih dari $10 \%$, sehingga $90 \%$ unsur hara $\mathrm{P}$ selama pertumbuhan diserap pada masa generatif. Selain itu, faktor lain yang kemungkinan mempengaruhi hasil biji sorgum adalah lingkungan. Selama stadia pemasakan biji, tanaman sorgum memerlukan kondisi lingkungan yang kering agar diperoleh kualitas yang baik. Kondisi lingkungan yang kering akan mendorong proses pemasakan biji lebih cepat dan bentuk biji lebih seragam (Ruminta et al., 2019)

Varietas yang digunakan memiliki kemampuan genetik yang berbeda-beda untuk menghasilkan ukuran dan berat biji yang terbentuk tanpa tergantung pada kondisi lingkungan (Tarigan et al., 2015)

\section{KESIMPULAN}

Dosis pupuk fosfor $100 \mathrm{~kg} / \mathrm{ha}$ merupakan dosis pupuk fosfor terbaik untuk varietas Numbu dan Kawali, dengan menghasilkan bobot malai pertanaman tinggi masing-masing yaitu $88,38 \mathrm{~g}$ dan 
71,33 g yang setara dengan 6 t/ha dan 4,8 t/ha.

\section{DAFTAR PUSTAKA}

Agustina, K., Sopandie, D., \& Wirnas, D. (2010). Tanggap Fisiologi Akar Sorgum (Sorghum bicolor L. Moench) terhadap Cekaman Aluminium dan Defi siensi Fosfor di dalam Rhizotron. Jurnal Agronomi Indonesia, 38(2): 88-94.

Balittan Sereal. (2014). Database Sorgum. https://balitsereal.litbang.pertanian.g o.id/varietas-sorgum/.

Ginting, R.C.B., Saraswati, R., \& Husein, E. (2010). Mikroorganisme Pelarut Fosfat. 7, 141-158. https://balittanah. litbang.pertanian.go.id/ind/dokument asi/buku/pupuk/pupuk7.pdf.

Hutauruk, F. I., Simanungkalit, T., \& Irmansyah, T. (2012). Pengujian pemberian fungi Mikoriza arbuskula dan pupuk fosfat pada budidaya tanaman sorgum (Sorghum bicolor (L.) Moench). Jurnal Online Agroekoteknologi, 1(1): 64-75.

Marlina, N., Iin S. A. R., \& Ramlan S. L. (2015). Aplikasi pupuk kandang kotoran ayam pada tanaman kacang tanah (Arachis Hypogeae L.). Biosaintifika Journal of Biology and Biology Education, 7(2): 136-141. https://doi.org/10.15294/biosaintifika .v7i2.3957

Nuryani, E., \& Haryono, G. (2019). Pengaruh Dosis dan saat pemberian pupuk $\mathrm{p}$ terhadap hasil tanaman buncis (Phaseolus vulgaris, L .) tipe tegak. Jurnal Imu Pertanian Tropika dan Subtropika, 4(1): 14-17.

Palmasari, B., \& Riani, E. (2019). Pengaruh pemberian pupuk fospat dengan dosis dan frekuensi berbeda terhadap pertumbuhan dan produksi kacang tanah (Arachis hypogaea L. Merr). Klorofil, 14(2): 98-101.
Prayudi, M. S., Barus, A., \& Sipayung, R. (2019). Respons pertumbuhan dan produksi tanaman okra (Abelmoschus esculantus L. Moench) terhadap waktu pemangkasan pucuk dan pemberian pupuk NPK. Jurnal Agroekoteknologi, 7(1): 72-80.

Puspitasari, H. M., Yunus, A., \& Harjoko, D. (2018). Dosis pupuk fosfat terhadap pertumbuhan dan hasil beberapa jagung hibrida. Agrosains, 20(2): 34-39. https://doi.org/10.2096 1/agsjpa.v20i2.22058.

Rahayu, M. A. (2012). Uji adaptasi beberapa varietas sorgum manis di lahan kering Wilayah Jawa Tengah dan Jawa Timur. Jurnal Caraka Tani, 27(1): 53-62.

Ruminta, R., Wahyudin, A., \& Ramdani, A. (2019). Respon hasil tanaman sorgum (Sorghum bicolor L. Moench) terhadap pupuk organik cair dan jarak tanam di Jatinangor Jawa Barat. Agrin, 22(2): 160-170. https://doi.org /10.20884/1.agrin.2018.22.2.464

Selvia, N., Mansyoer, A., \& Sjofjan, J. (2014). Pertumbuhan dan produksi tanaman sorgum (Sorghum bicolor L.) dengan Pemberian beberapa kombinasi kompos dan pupuk $\mathrm{P}$. Jurnal Online Mahasiswa Fakultas Pertanian, 1(2): Oktober 2014.

Siregar, H. (2019). Pengaruh Pemberian Biochar dari Berbagai Sumber dan Pupuk Kandang Sapi terhadap Pertumbuhan dan Produksi Tanaman Padi Sawah (Oryza sativa L.) [Skripsi Fakultas Pertanian, Universitas Medan Area].

Sitepu, L., \& Elza Z. N. (2015). Aplikasi beberapa dosis pupuk fosfor untuk pertumbuhan dan produksi beberapa varietas sorgum (Sorghum bicolor [L] Moench). Jurnal Online Mahasiswa Fakultas Pertanian, 2(2): Oktober 2015.

Subagio, H., Aqil, M., Penelitian, B., \& 
Serealia, T. (2013). Pengembangan Produksi Sorgum di Indonesia. Seminar Nasional Inovasi Teknologi Pertanian, 199-214. http://kalsel. litbang.pertanian.go.id/ind/images/pd f/prosiding/20\%20herman.pdf .

Suhardedi, C. (2015). Potensi sorgum sebagai bahan pangan fungsional. Iptek Tanaman Pangan, 7(1): 1-3.

Suranto, H., Sjofjan, J., \& Yoseva, S. (2015). Pemberian abu sekam padi dengan pupuk NPK terhadap pertumbuhan dan produksi tanaman jagung manis (Zea mays saccharata Sturt.) pada tanah gambut. Jurnal Online Mahasiswa Fakultas Pertanian, 2(1): Februari 2015.

Talanca, A. H., \& Andayani, N. N. (2014). Perkembangan Perakitan Varietas Sorgum di Indonesia. In Sumarno., Djoko, S. D., Mahyuddin, S., \& Hermanto (eds). Buku Sorgum: Inovasi Teknologi dan
Pengembangan (pp. 94-106). IAARD Press. http://sidolitkaji.litbang. pertanian.go.id/i/files/Sorgum.pdf.

Tarigan J. A., \& Zuhry, E. N. (2015). Uji daya hasil beberapa genotipe sorgum manis (Sorghum bicolor (L.) Moench) koleksi Batan. Jurnal Online Mahasiswa Fakultas Pertanian, 2(1): Februari 2015.

Wahyuningrum, M.A., Endang, D.P., \& Lukiwati, D. R. (2015). Produksi hijauan pakan sorgum (Sorghum Bicolor Var. Numbu) Dengan pemupukan fosfat dan nitrogen. Jurnal Ilmiah Respati Pertanian, 1(6): 1-8.

Winata, N. A. S. H., Lukiwati, D. R., \& Purbajanti, E. D. (2014). Kualitas biji sorgum manis Varietas Numbu dengan pemberian pupuk sumber fosfat yang berbeda. Agrovigor, 7(1): 63-69. 